\title{
Ocena skuteczności wybranych zabiegów fizykoterapeutycznych u pacjentów ze zmianami zwyrodnieniowymi stawów kolanowych
}

\section{Evaluation of the effectiveness of selected physiotherapy treatments in patients with degenerative disease of the knee joint}

\author{
Żaneta Ciosek ${ }^{1 凶}$, Aleksandra Szylińska', Łukasz Kopacz ${ }^{2}$, Karolina Kot ${ }^{3}$, Iwona Rotter ${ }^{1}$ \\ 1 Pomorski Uniwersytet Medyczny w Szczecinie, Zakład Rehabilitacji Medycznej i Fizjoterapii, ul. Żołnierska 54, 71-210 Szczecin \\ 2 Pomorski Uniwersytet Medyczny w Szczecinie, Samodzielna Pracownia Propedeutyki i Fizykodiagnostyki Stomatologicznej, \\ al. Powstańców Wlkp. 72, 70-111 Szczecin \\ ${ }_{3}^{3}$ Pomorski Uniwersytet Medyczny w Szczecinie, Katedra i Zakład Biologii i Parazytologii Medycznej, al. Powstańców Wlkp. 72, 70-111 Szczecin \\ $\triangle$ ciosekzaneta@gmail.com
}

\begin{abstract}
Introduction: Knee osteoarthritis is one of the most common disorders of the musculoskeletal system. This is a chronic and progressive disease. The symptoms of gonarthritis are the pain in the anterior or medial part of the knee, oedema and the limited range of motion.

The aim of the study was to compare the effectiveness between ultrasound method applied separately and in conjunction with transcutaneous electrical nerve stimulation in patients with pain syndrome and lower range of motion, which were caused by degenerative disease of the knee joint.

Materials and methods: The study group included 84 patients with gonarthritis. The symptoms of the disease were chronic knee pain and mobility limitation of the knee joint. The patients were randomly divided into two groups of 42 participants. In the first group, the patients ( 23 female and 19 male) had 10 sessions of transcutaneous electrical nerve stimulation and 10 ultrasound therapy sessions. In the second group, the participants
\end{abstract}

\section{ABSTRAKT}

Wstęp: Choroba zwyrodnieniowa stawów kolanowych (chzsk) jest jednym z najczęściej występujących schorzeń układu ruchu. Zaliczana jest do chorób przewlekłych i postępujących. Objawia się dolegliwościami bólowymi w przedniej lub przyśrodkowej części kolana, obrzękiem oraz ograniczeniem zakresu ruchomości. Celem badań było porównanie skuteczności prądu TENS i fali ultradźwiękowej oraz samodzielnie wykonywanego zabiegu falą ultradźwiękową u pacjentów z dolegliwościami bólowymi oraz ograniczeniem zakresu ruchu spowodowanym chzsk.

Materiały i metody: W badaniu wzięło udział 84 pacjentów z chzsk manifestującą się przewlekłymi dolegliwościami bólowymi oraz ograniczeniem ruchomości. W sposób losowy dokonano podziału na dwie 42-osobowe grupy. W grupie I (23 kobiety i 19 mężczyzn) wykonano 10 zabiegów prądami TENS oraz 10 zabiegów falą ultradźwiękową. W grupie II (25 kobiet i 17 mężczyzn) wykonano 10 zabiegów falą ultradźwiękową. Przed
(25 female and 17 male) underwent 10 ultrasound therapy sessions. Before and after researches in both groups measurement of the mobility of the knee joint and questionnaire about pain syndrome (VAS scale) was done.

Results: We observed better effects of therapy in the group of patients who were subjected to transcutaneous electrical nerve stimulation in conjunction with ultrasound therapy than in the group of participants who underwent only ultrasound therapy. We found statistically significant differences in the range of mobility in flexion as well as extension, and in the intensity of pain. There were no statistically significant differences between women and men in both groups.

Conclusions: The use of transcutaneous electrical nerve stimulation in conjunction with ultrasound therapy has better effects in the rehabilitation of patients with knee osteoarthritis than the use of ultrasound therapy. The sex of the patients has no influence on the treatment's effectiveness.

Keywords: pain; knee joint; osteoarthritis. przystąpieniem do badań oraz po skończonej serii zabiegów w obu grupach wykonano pomiar zakresu ruchomości stawu kolanowego oraz zebrano wywiad dotyczący dolegliwości bólowych (VAS).

Wyniki: W grupie, w której wykonano zabieg prądami TENS i falą ultradźwiękową, wykazano lepsze efekty terapii niż u osób, u których zastosowano tylko zabieg falą ultradźwiękową. Istotne statystycznie różnice obejmowały zakres ruchu zgięcia, wyprostu oraz natężenia bólu. W analizie pomiędzy kobietami a mężczyznami w obydwu grupach nie wykazano różnic istotnych statystycznie. Wnioski: Lepsze efekty rehabilitacji u pacjentów ze zmianami zwyrodnieniowymi stawów kolanowych przynosi zastosowanie prądów TENS i fali ultradźwiękowej niż zastosowanie samej fali ultradźwiękowej. Kobiety i mężczyźni uzyskują podobne efekty po seriach zabiegów.

Słowa kluczowe: ból; staw kolanowy; choroba zwyrodnieniowa stawów.

\section{WSTEP}

Choroba zwyrodnieniowa stawów kolanowych (chzsk) jest jednym z najczęściej występujących schorzeń układu ruchu. Zaliczana jest do chorób przewlekłych i postępujących. Polega na uszkodzeniu i utracie chrząstki stawowej na skutek zaburzonej równowagi między enzymami powodującymi degenerację chrząstki a czynnikami odpowiedzialnymi za jej odnowę [1]. Choroba zwyrodnieniowa stawów kolanowych znajduje się 
na trzecim miejscu za zmianami zwyrodnieniowymi kręgosłupa i stawów biodrowych. Dotyczy 10-20\% ludzi na całym świecie w wieku 65-74 lat oraz 30\% populacji powyżej 75. r.ż. [2] Ze względu na zwiększającą się liczbę osób starszych w Europie oraz wielu młodych uprawiających sport obciążający stawy kolanowe wzrasta odsetek zachorowań na osteoartrozę. Choroba zwyrodnieniowa stawów kolanowych objawia się dolegliwościami bólowymi w przedniej lub przyśrodkowej części kolana, obrzękiem oraz ograniczeniem zakresu ruchomości [3]. Na przyczynę choroby składa się wiele czynników, m.in.: starzenie, płeć, otyłość, czynniki genetyczne, przebyte urazy oraz nadmierne obciążenia [4]. Obecna terapia skupia się na złagodzeniu objawów dzięki różnym metodom. Ćwiczenia poprawiające stabilizację oraz metody fizykalne mają za zadanie uśmierzyć ból i poprawić zakres ruchomości stawów kolanowych [5].

Elektrostymulacja TENS (transcutaneous electrical nerve stimulation) jest zabiegiem fizykoterapeutycznym zaliczanym do działu elektrolecznictwa. Wykorzystuje prądy małej częstotliwości o czasie trwania impulsu 50-300 $\mu$ s i częstotliwościach 0,5-500 Hz z natężeniem prądu na poziomie progowym lub podprogowym [6]. Rozróżnia się 4 rodzaje prądu: o małej częstotliwości (1-2 Hz), o dużej częstotliwości (50-200 Hz), o krótkich impulsach (0,01-3 ms), o długich impulsach (10-60 ms). W elektrostymulacji TENS najczęściej stosuje się prądy impulsowe o wysokiej częstotliwości, mieszczącej się w granicach 80-100 Hz, czyli tzw. stymulację konwencjonalną. Polega ona na wysyłaniu impulsów elektrycznych o niskiej amplitudzie z elektrod do nerwów obwodowych, gdzie następnie kierowane są do połączeń synaptycznych rdzenia kręgowego. Tam blokują impuls nerwowy niosący sygnał o bólu, a mózg nie otrzymuje danych co do miejsca i nasilenia dolegliwości. Koncepcja ta została przyjęta przez naukę w latach 60. XX w. jako teoria bramek bólowych Walla i Melzacka [7].

Ultradźwięki są to fale mechaniczne o częstotliwości powyżej $20 \mathrm{kHz}$, ale ze względu na właściwości fizyczne w fizykoterapii stosuje się fale $1 \mathrm{MHz}$ i $3 \mathrm{MHz}$. Swoje efekty elektrostymulacja zawdzięcza działaniu mechanicznemu, tzw. mikromasażowi, który polega na wytworzeniu zmiennego ciśnienia zlokalizowanemu w obszarze terapeutycznym [8]. Doprowadza on do zwiększonej przepuszczalności przez błony komórkowe oraz przyspiesza proces metaboliczny. Dodatkowo fala ultradźwiękowa prowadzi do rozgrzania tkanek, a wytworzone ciepło powstaje dzięki wchłanianiu przez tkanki energii fal. Wskutek tego następuję podniesienie progu bólu, rozluźnienie mięśni oraz zmiany w przewodnictwie nerwowym [9].

Celem badań było porównanie skuteczności prądu TENS i fali ultradźwiękowej oraz samodzielnie wykonywanego zabiegu falą ultradźwiękową u pacjentów z dolegliwościami bólowymi, a także ograniczeniem zakresu ruchu spowodowanym chzsk.

\section{MATERIAtY I METODY}

Badania przeprowadzono od marca do listopada 2016 r. w Poradni Rehabilitacji w Szczecinie wśród 84 pacjentów z chzsk manifestującą się przewlekłymi dolegliwościami bólowymi oraz ograniczeniem ruchomości stawów kolanowych. Przedział wiekowy wśród badanych wynosił 65-83 lat, a średnia wieku 68,5 lat. W sposób losowy dokonano podziału na dwie 42-osobowe grupy. W grupie I (23 kobiety i 19 mężczyzn) wykonano 10 zabiegów prądami TENS oraz 10 zabiegów falą ultradźwiękową. W grupie II (25 kobiet i 17 mężczyzn) wykonano 10 zabiegów falą ultradźwiękową. Przed przystąpieniem do badań i po skończonej serii zabiegów w obu grupach wykonano pomiar zakresu ruchomości stawu kolanowego (zgięcie i wyprost) oraz zebrano wywiad dotyczący dolegliwości bólowych (za pomocą wizualnej skali analogowej Visual Analogue Scale - VAS). Kryterium włączenia do badań stanowiły zdiagnozowana gonartroza min. 5 lat temu, a także ograniczenie zgięcia i wyprostu w stawie kolanowym. Kryterium wyłączenia z badań dotyczyło stanu po alloplastyce stawu kolanowego, metalowych elementów w ciele, niedowładu połowiczego, zaburzenia czucia, choroby nowotworowej, stanu zapalnego. Każdy pacjent wyraził zgodę na uczestnictwo w anonimowych badaniach oraz został poinformowany o przebiegu i technice.

\section{Pomiar ruchomości stawów kolanowych}

W trakcie pomiaru zakresu ruchomości stawu kolanowego pacjent znajdował się na leżance, w pozycji leżenia na brzuchu. Kończyny dolne były wysunięte poza podłoże, tak aby staw kolanowy i staw skokowy nie były podparte. Badanie przeprowadzane było w płaszczyźnie strzałkowej. Oś goniometru znajdowała się w okolicy głowy strzałki, zgodnie z osią poprzeczną stawu. Skala goniometru skierowana była ku górze przy badaniu zgięcia oraz ku dołowi podczas badania wyprostu. Ramię nieruchome przebiegało wzdłuż osi długiej kości udowej i skierowane było w stronę krętarza większego kości udowej, natomiast ramię ruchome ustawione było wzdłuż podudzia i skierowane w stronę kostki bocznej kości strzałkowej. W trakcie badania ramię ruchome podążało za podudziem, a ramię nieruchome pozostawało w pozycji wyjściowej [10]. Prawidłowe zakresy ruchów w stawie kolanowym wg ISOM (International Standard Ortopedic Measurement) wynoszą dla zgięcia $130-135^{\circ}$, natomiast dla wyprostu $0^{\circ}[11]$.

\section{Fala ultradźwiękowa}

Nadźwiękawianie stawu kolanowego odbywało się metodą dynamiczną, opierającą się na wykonywaniu kolistych ruchów wokół rzepki, gdzie pojedyncze okrążenie trwało 2-3 s, a cały zabieg $5 \mathrm{~min}$. W badaniach wykorzystano dawkę 0,5 W/cm², częstotliwość nośną $1 \mathrm{MHz}$ oraz tryb impulsowy 50\% (1:2). Wielkość głowicy, którą wykonano ultradźwięki wśród badanych pacjentów, wynosiła $5 \mathrm{~cm}^{2}$. Powierzchnia skóry miejsca poddanego zabiegowi była oczyszczona, bez kremów i maści. Jako substancję sprzęgającą użyto neutralnego żelu. Przed badaniem przeprowadzony został wywiad z każdym pacjentem w celu wyeliminowania przeciwwskazań do wykonania zabiegu.

\section{TENS}

Do zabiegu raz dziennie wykorzystano prądy TENS o kształcie prostokąta, częstotliwości $100 \mathrm{~Hz}$ i czasie impulsu $50 \mu \mathrm{s}$. Mokre podkłady z gazy wraz z elektrodami węglowymi $(50 \times 70 \mathrm{~mm})$ 
zostały ułożonego po obu stronach stawu kolanowego; katoda w miejscu bardziej bolesnym (ułożenie poprzeczne). Elektrody były zabezpieczone rzepą, aby zapobiec przesunięciu. Skóra w miejscu zabiegowym została oczyszczona za pomocą środka do odkażania. Natężenie prądu było dostosowane do odczuć pacjenta, pozostając wyraźne, ale niebolesne. Po 15 min zabiegu, jeśli dochodziło do osłabienia odczuwanych wrażeń, zwiększano natężenie prądu. Zabiegi wykonywano w leżeniu tyłem z półwałkiem ułożonym pod stawem kolanowym pacjenta. Czas jednego zabiegu wynosił 30 min i wykonywany był przy użyciu aparatu BTL-5620.

\section{Analogowa skala bólu VAS}

Do pomiaru natężenia bólu przed rozpoczęciem badań oraz tuż po ich zakończeniu wykorzystano 10-stopniową skalę wzrokowo-analogową (VAS), zgodnie z którą chory określał stopień natężenia dolegliwości bólowych, gdzie o oznaczało brak bólu, a 10 - najgorszy ból, jaki można sobie wyobrazić.

\section{Analiza statystyczna}

Do analizy statystycznej danych wykorzystano licencjonowany program Statistica 12 (StatSoft, Inc. Tulsa, OK, USA). Do oceny normalności rozkładu zastosowano test Shapiro-Wilka.
Do oceny istotności statystycznej przed i po serii zabiegów wykorzystano test t-Studenta lub test Wilcoxona. W porównaniach między grupami w zależności od zastosowanych zabiegów wykorzystano głównie test t-Studenta dla prób niezależnych lub test U Manna-Whitneya. Istotność statystyczna została określona przy wartości $\mathrm{p}<0,05$.

\section{WYNIKI}

W grupie badanej przeprowadzono analizę różnic pomiędzy grupą pacjentów zakwalifikowanych na zabiegi prądami TENS i ultradźwiękami a grupą pacjentów przyjętych tylko na zabiegi falą ultradźwiękową. Wyniki zebrano w tabeli 1. Po serii zabiegów w grupie I i grupie II zaobserwowano wzrost ruchomości stawu kolanowego w zakresie zgięcia $(\mathrm{p}<0,001)$ i wyprostu $(\mathrm{p}<0,001)$ oraz spadek natężenia bólu $(\mathrm{p}<0,001)$. W ocenie międzygrupowej lepsze efekty po serii zabiegów wykazano po zastosowaniu prądów TENS i fali ultradźwiękowej; istotne różnice obejmowały zakres ruchu zgięcia $(\mathrm{p}=0,03)$, wyprost ( $p=0,003)$ oraz natężenie bólu $(p=0,021)$.

Porównanie skuteczności zabiegów przed i po rehabilitacji w zależności od płci badanych w grupie I i grupie II

TABELA 1. Porównanie między grupami zakresów ruchomości oraz natężenie bólu w stawie kolanowym

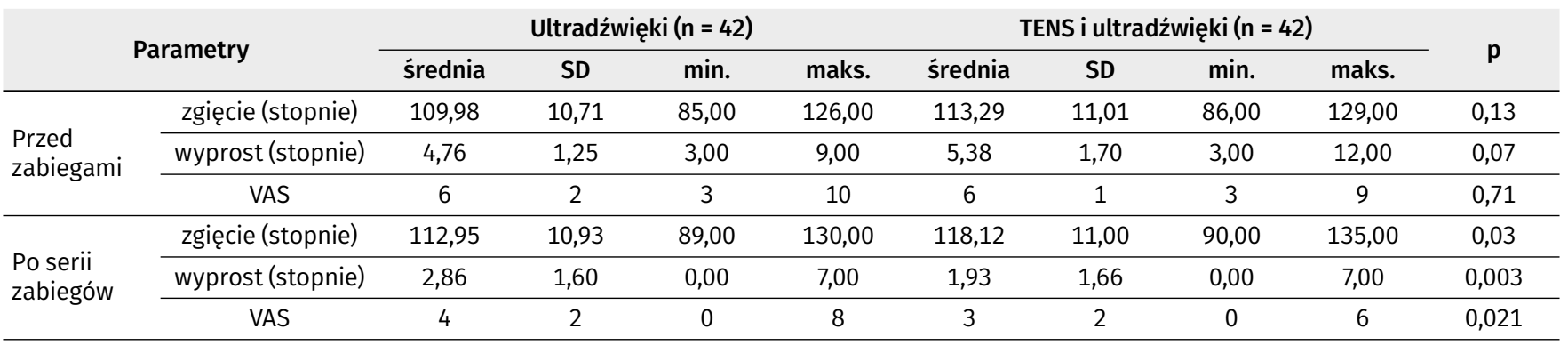

TABELA 2. Różnice zakresów ruchomości w stawie kolanowym oraz natężenia bólu przed serią oraz po serii zabiegów w zależności od płci badanych

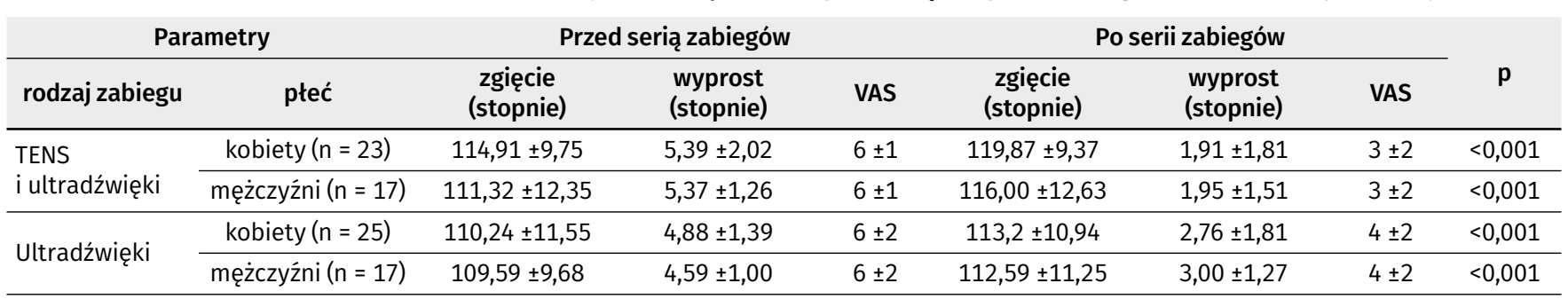

TABELA 3. Różnice zakresów ruchomości w stawie kolanowym oraz natężenia bólu w zależności od ptci badanych

\begin{tabular}{|c|c|c|c|c|c|c|c|c|c|c|}
\hline & & \multicolumn{9}{|c|}{ Ultradźwięki } \\
\hline \multirow{2}{*}{\multicolumn{2}{|c|}{ Parametry }} & \multicolumn{4}{|c|}{ kobiety $(n=25)$} & \multicolumn{4}{|c|}{ mężczyźni (n = 17) } & \multirow{2}{*}{$p$} \\
\hline & & średnia & SD & $\min$. & maks. & średnia & SD & $\min$. & maks. & \\
\hline \multirow{3}{*}{$\begin{array}{l}\text { Przed } \\
\text { rehabilitacją }\end{array}$} & zgięcie (stopnie) & 110,24 & 11,55 & 85,00 & 126,00 & 109,59 & 9,68 & 89,00 & 122,00 & 0,71 \\
\hline & wyprost (stopnie) & 4,88 & 1,39 & 3,00 & 9,00 & 4,59 & 1,00 & 3,00 & 6,00 & 0,44 \\
\hline & VAS & 6 & 2 & 3 & 10 & 6 & 2 & 4 & 8 & 0,95 \\
\hline \multirow{2}{*}{$\begin{array}{l}\text { Po serii } \\
\text { zabiegów }\end{array}$} & wyprost (stopnie) & 2,76 & 1,81 & 0,00 & 7,00 & 3,00 & 1,27 & 1,00 & 6,00 & 0,69 \\
\hline & VAS & 4 & 2 & 0 & 7 & 4 & 2 & 2 & 8 & 0,70 \\
\hline
\end{tabular}


zamieszczono w tabeli 2. Kobiety i mężczyźni w analizowanych grupach uzyskali zwiększenie zakresu ruchu zgięcia $(p<0,001)$ oraz wyprostu $(\mathrm{p}<0,001)$ w stawie kolanowym oraz spadek natężenia bólu $(\mathrm{p}<0,001)$. W ocenie różnic pomiędzy kobietami a mężczyznami w obydwu grupach nie wykazano istotnych statystycznie różnic (tab. 3).

\section{DYSKUSJA}

W przeprowadzonych badaniach uwzględniono wpływ zabiegów z zakresu fizykoterapii (TENS, UD) w przebiegu zmian zwyrodnieniowych stawów kolanowych, ze szczególnym uwzględnieniem dolegliwości bólowych i zakresu ruchu w płaszczyźnie strzałkowej. Na podstawie badań stwierdzono znaczne zmniejszenie dolegliwości bólowych, a także wzrost zakresu czynnego ruchu w stawach w efekcie połączenia obu omawianych czynników fizykalnych. Wyniki przeprowadzonych badań potwierdzają spostrzeżenia innych autorów, którzy zwracali szczególną uwagę na wpływ zabiegów prądami TENS oraz falą ultradźwiękową w chzsk.

Pop i wsp. badaniami objęli 60 osób, które zostały podzielone na grupę chorych leczonych zachowawczo (31 osób) i chorych po zabiegu alloplastyki stawu kolanowego (29 osób), którzy byli leczeni na Oddziale Ortopedii Dorosłych oraz rehabilitowani w Pracowni Fizjoterapii Szpitala Wojewódzkiego w Rzeszowie. Z uzyskanych odpowiedzi wynika, że chorzy leczeni zachowawczo najczęściej podawali zabiegi krioterapii, pola magnetycznego, światła laserowego i ultradźwięki jako zabiegi znoszące ból [2].

Analizując wyniki badań własnych, można zauważyć, iż w skutek zastosowania zabiegu falą ultradźwiękową także uzyskano zmniejszenie odczuwanych przez pacjentów dolegliwości bólowych związanych z chzsk.

Jaźwa i wsp. w grupie 50 pacjentów, u których stwierdzono chzsk, przeprowadzili badanie 2-krotnie. Pierwsze przed serią 10 zabiegów (jonoforeza - UD) oraz drugie po 2 tygodniach. Ocenie poddano funkcjonalność pacjentów, intensywność bólu, możliwości wykonywania podstawowych czynności życia codziennego oraz zbadano zakres ruchu w stawie. Na podstawie analizy zgromadzonych wyników badań wykazano poprawę stanu pacjentów w zakresie zmniejszenia dolegliwości bólowych, w zakresie wykonywania podstawowych czynności dnia codziennego oraz poprawę funkcjonalną stawu kolanowego. Zwiększeniu uległ również zakres ruchu w stawie.

Odnosząc się do przeprowadzonych badań, należy wskazać, iż w grupie badanych pacjentów poddanych terapii falą ultradźwiękową wraz ze zmniejszeniem dolegliwości bólowych odnotowano również zwiększenie zakresu ruchu w stawie kolanowym [12].

W badaniach, które przeprowadzili Kędzierski i wsp., 50 osób podzielono na dwie grupy po 25 pacjentów. W grupie pierwszej chorzy otrzymali 10 zabiegów z wykorzystaniem terapii zsynchronizowanym promieniowaniem laserowym. W grupie drugiej pacjenci zostali poddani 10 zabiegom z zastosowaniem prądów TENS niskiej częstotliwości. Zabiegi były wykonywane codziennie przez 2 tygodnie. W badaniach oceniono ból omawianej okolicy oraz uwzględniono zmodyfikowany kwestionariusz Laitinena. Na podstawie wyników wskazano, iż w efekcie zastosowanej terapii uzyskano poprawę w zakresie zmniejszenia dolegliwości bólowych w obu grupach. Poprawa ta była istotnie większa w grupie pacjentów leczonych dwufazową laseroterapią. Nie zaobserwowano poprawy zakresu ruchów w stawie kolanowym po przeprowadzonej terapii [13].

Badania własne pozwoliły udowodnić, iż wykorzystanie prądów TENS w terapii pacjentów z chzsk zmniejsza dolegliwości bólowe omawianej okolicy, a także pozwala na zwiększenie zakresu ruchomości stawu.

Baumgart i wsp. badali ocenę dwóch metod elektroterapeutycznych - prądów interferencyjnych (IFC) i przezskórnej stymulacji nerwów (TENS). Analiza uzyskanych przez autorów wyników badań wykazała, iż zarówno elektrostymulacja IFC, jak i TENS są skutecznymi metodami w zmniejszaniu objawów zmian zwyrodnieniowych stawów kolanowych. Wyniki między badanymi grupami nie wykazywały różnic istotnych statystycznie [14].

W oparciu o wszystkie przedstawione wyniki przeprowadzonych badań udowodniono, jak ważną rolę odgrywa w postępowaniu fizjoterapeutycznym działanie analgetyczne, a także poprawiające funkcjonalność zmienionej chorobowo okolicy. W badaniach własnych udowodniono korzystne działanie zarówno prądów TENS, jak i fali ultradźwiękowej. Łącząc omawiane czynniki fizykalne, zdecydowanie poprawia się ich skuteczność, dzięki czemu pacjenci cierpiący na choroby wiążące się z silnymi dolegliwościami bólowymi mogą ograniczyć zażywanie wielu leków przeciwbólowych.

\section{WNIOSKI}

Lepsze efekty rehabilitacji w zakresie ruchomości stawu kolanowego i natężenia bólu u pacjentów ze zmianami zwyrodnieniowymi stawów kolanowych przynosi zastosowanie prądów TENS i fali ultradźwiękowej niż zastosowanie samej fali ultradźwiękowej. Kobiety i mężczyźni uzyskują podobne efekty po seriach zabiegów.

\section{PIŚMIENNICTWO}

1. Montrull HL. Structure and secretory activity of cultured chondrocytes from patients with osteoarthritis. Biocell 2005;29(2):163-7.

2. Pop T, Hamerla K, Przysada G. Czynniki wpływające na redukcję bólu u chorych z chorobą zwyrodnieniową stawów kolanowych. Prz Med Uniw Rzesz 2007;4:335-45.

3. Trybulec B, Barłowska-Trybulec M, Manko G. Terapia manualna w zmianach zwrodnieniowych stawów kolanowych - przegląd techniki. Rehabil Prakt 2011;4:42-4.

4. Sierakowska M. Ocena jakości życia pacjentów. Reumatologia 2006;44:298301.

5. Jordan KM, Arden NK, Doherty M, Bannwarth B, Bijlsma JWW, Dieppe P, et al. Leczenie choroby zwyrodnieniowej stawu kolanowego. Aktualne zalecenia European Laegue Against Rheumatism. Med Prakt 2004;3:95-104. 
6. Liana R, Chudański M, Ponikowska I. Prądy TENS, Traberta oraz Kotsa w terapii fizykalnej. Baln Pol 2008;50(1):5-12.

7. Pyszora A, Kujawa J. Elektroterapia bólu. Pol Med Paliatywna 2003;3:167 73.

8. Grubisić F, Grazio S, Jajić Z, Nemcić T. Therapeutic ultrasound in chronic low back pain treatment. Reumatizam 2006;53(1):18-21.

9. Miłowska K. Ultradźwięki - mechanizmy działania i zastosowanie w terapii sonodynamicznej. Post Hig Med Dośw 2007;61:338-49.

10. Zembaty A. Kinezyterapia. Kraków: Firma Handlowo-Usługowa „Kasper”; 2002.

11. Kilar JZ, Lizis P. Leczenie ruchem. Część I: Badanie narządu ruchu w rehabilitacji. Kraków: Firma Handlowo-Usługowa „Kasper”; 2002.
12. Jaźwa P, Trojan G, Jaźwa M, Rojek A. Ocena wpływu wybranych zabiegów fizjoterapeutycznych na wyniki leczenia choroby zwyrodnieniowej stawu kolanowego. Young Sport Sci Ukraine 2011;3:325-8.

13. Kędzierski T, Stańczak K, Gworys K, Gasztych J, Sibiński M, Kujawa J. Ocena porównawcza bezpośredniej skuteczności przeciwbólowej wybranych metod fizjoterapii u osób z chorobą zwyrodnieniową stawów kolanowych. Doniesienie wstępne. Ortop Traumatol Rehabil 2012;6(6);14:537-44. doi: 10.5604/15093492.1024718.

14. Baumgart M, Kapsa A, Weber-Rajek M, Radzimińska A, Szyper S, Szpinda M, et al. Ocena skuteczności różnych form elektroterapii w leczeniu objawów zmian zwyrodnieniowych stawów kolanowych. J Educ Health Sport 2016;6(5):131-8. doi: 10.5281/zenodo.51333. 